\title{
Leveraging of Sport Events to Support Tourism in Egypt
}

\author{
Dalia Zaki
}

The High Institute for Tourism, Hotels and Computer, Alexandria, Egypt

\begin{abstract}
Sport events attract large spectators from local residents and international tourists and provide worldwide media coverage. Nowadays, there is a great global competition among destinations for hosting sport events; accompanied by leverage programs. The phenomenon of event leverage maximizes both short and long-term outcomes. So sport event leverage involves planning long- term outcomes from such events, to promote tourism and develop local business, besides, short-term outcomes such as: visitationrelated impacts. The research initiative focuses on tourists' intentions to visit Egypt for attending a sport event. Moreover, the research implies to the benefits generated from sport events, which may support tourism in Egypt. To carry on with this research a questionnaire survey was conducted among non- sport tourists visiting Egypt. The findings identified some key factors that influence tourists' intentions to visit Egypt for sport tourism. The research showed also that Egypt has the capabilities that allow it to compete strongly with other countries in both hosting and organizing sport events, as well as applying leverage programs to support tourism.
\end{abstract}

Keywords: Egypt, Event Leverage, Sport Events, Sport Tourism, Visiting Intention.

\section{Introduction}

Sport tourism is the fastest growing segment in the tourism industry (Priestley, 1995). It was estimated that internationally sport tourism accounted for \$7.68 trillion, 23.9 million sports tourists or 10 percent of the international tourism market in 2011 (Schumacher, 2012). Some of the contributing factors to the growth of sport tourism include: expansion in the number of participants worldwide in a variety of professional and leisure sport leagues; increased general admiration of sports; an increase of travelers who plan their vacations around sport events; and exponential growth of popularity in 'active lifestyles' (Green and Chalip, 1998). Sport tourism can take many forms including: participation in 'club' sport events, sport tours, sport cruises, sport conferences, sport camps (Kurtzman and Zauhar, 2005), sports training and sports events (Weed, 2009; Weed and Bull, 2004).

The concept of 'sports events' is considered one of the most important components of sport tourism nowadays, because of its important role in destination promotion (Deery et al., 2004; Getz, 2003; Jiménez-Naranjo, 2016) and attracting a large number of national and international participants and attendees (Kim and Walker, 2012; Papanikos, 2015; Ritchie et al., 2009). The sport events are known as either small, medium, major or mega events (Pranic' et al., 2012). However, mega events are defined as 'large-scale cultural (including commercial and sporting) events, which have dramatic character, mass popular appeal and international significance' (Roche, 2000, p.1). Furthermore, the volume of a sport mega event should exceed one million visits and its reputation should be that of a 'must see' event (Marris, 1987). Apparent from the Olympics Games and the FIFA World Cup that are considered as mega events, others fall below the one million visitors' criteria may not be considered a mega event, but rather a major or medium sport event (Pranic et al., 2012), which includes events held annually such as: Wimbledon or the Super Bowl (Gibson, 2012; Gratton, 2000). While, Higham (1999, p. 87) defines small scale-sports events as 'regular season sporting competitions (ice hockey, basketball, soccer, rugby leagues), domestic competitions or disabled sports and the like', in addition to collegiate athletic championships (Gibson, 2003). 
Regardless of size, sport events are recognized internationally as an important component of tourism development and good opportunities for economic growth (Kim and Walker, 2015; Konstantaki and Wickens, 2010; Tassiopoulos, 2005). The importance of hosting sport event can be credited to its contributions to the destination for example: destination branding, enhancing image, tourism promotion, encouraging repeat visitation, improvement of occupancy and overcoming seasonality (Getz, 1997). Moreover, sport events can help the host community well-fare, through increases in employment, income, investment, as well as a new source of entertainment and enhancements to quality of life (Deccio and Baloglu, 2002), especially underdeveloped countries (Honaria, 2010).

It is worth to mention in this context that some destinations at some time might encounter difficulties and crises as a result of natural disaster, war, terrorism, crime waves, economic recession or political instability (Avraham and Ketter, 2013). Such occurrences hold potential tourists from visiting the destination (Beirman, 2003; Richie, 2009). Thus, hosting sport events concentrate media's attention on the destination for a short period of time and create opportunities to attract international visitors to a destination they might never consider visiting (Avraham, 2014).

Previous empirical studies had focused on the impact of sports events on host destinations from the perception of sport tourism spectators and participants. However, little studies investigated the impact of such events on non-sport tourists (Dongfeng, 2013). The impact on tourists in general is an important indicator of a sport event's economic impact, as the purpose of sport events is to build visitation at other times of the year (Chalip et al., 2003). So, marketers rely on sport events to create awareness and generate future inbound travel (Dimanche, 2003).

Accordingly, this research initiative is based upon the tourists' intentions to visit Egypt for attending a sport event. Moreover, the research implies to the benefits generated from such sport events, which may support tourism in Egypt. The research asks the following research questions:

RQ1: What types of sport events are attractive to tourists?

RQ2: What are the factors that influence tourists' intentions to visit Egypt for sport tourism?

RQ3: Do socio-demographic variables affect tourists' intentions to visit Egypt for sport tourism?

The paper begins by introduction where related literature is first presented and an overview of the sport events hosted by Egypt is then provided. Next, the research methodology that is employed is described. Then, the findings from the questionnaire survey are discussed. Finally, conclusions are given. Recommendations for implications and future research are also provided.

\section{Literature review}

Sport tourism is defined generally, as 'travel to participate in a sport activity, travel to observe sport, and travel to visit a sport attraction' (Delpy, 1998, p. 23). However, 'sport tourism events refer to those sport activities that attract tourists of which a large percentage are spectators and have the potential to attract non-residents, media, technical personnel, athletes, coaches and other sporting officials' (Kurtzman and Zauhar, 2003, p. 44). Other definition is developed to better describe tourists' needs and motivations such as: 'watching sporting events, visiting sports related attractions and active (sport) participation' (Gibson, 1998, p. 156).

It could be realized that sport tourism is divided into three different categories. The first category is spectators. Spectatorship of sport events has significantly emerged in the past few years (Kurtzman and Zauhar, 2005). Hence, 'it is the game or event that represents the 
(main) product in the spectator sports market' (Fullerton and Mertz, 2008, p. 93). The second category is sport attraction visitors, which can be divided into two sub categories: celebrity and nostalgia sport tourists (Gibson, 1998). Celebrity sport tourism includes group social trips and events; which involve chances to meet or watch legends of a sport, themed sports cruises with opportunities to meet famous coaches or players, or group bus tours for passion sports participants (Fairley and Gammon, 2005). Nostalgia sport tourists travel to visit halls of fame, hallmark sport facilities or other sport-related significance places or are historically important to sports fans (Roche et al., 2013). Hence, nostalgia sport tourism includes two forms: 'nostalgia for sport place or artifact and nostalgia for social experience' (Fairley and Gammon, 2005, p. 1). The third category is active participants; includes leagues, tournaments and competitions, where athletes can compete formally and informally in a sport (Roche et al., 2013). To enhance this segment, marketers should 'increase the number of participants and the frequency of participation in a specific activity' (Fullerton and Mertz, 2008, p. 93). So, for an event, this involves attracting leagues, teams and athletes to sport competitions, while, for a destination, this involves hosting sport events and attracting participants to leverage the economic benefits for the destination (Roche et al., 2013).

Nowadays, there is a great global competition among destinations for hosting sport events. Mainly due to its short-term outcomes such as: visitation-related impacts which remains a priority, but now stakeholders in some of the world's mega events leverage for long-term outcomes such as: repeat visitation to the host destinations, re-imaging of the host cities, and encouraging employment, local trade, business and investment (O'Brien and Chalip, 2008). This phenomenon of event leverage is known for maximizing both short and longterm event outcomes (Chalip, 2004). In other words, instead of looking back at the event outcomes, a leveraging standpoint involves looking forward to plan sustainable benefits from sport events, whether to enhance tourism and business development, social aspects, or other types of benefits (Chalip, 2007). Indeed, every mega sport events that took place in the last few years, for example: the 2002, 2006 and 2010 Commonwealth Games in Manchester, Melbourne, and New Delhi, respectively, the 2003 Brisbane Rugby World Cup, and at every Olympic Games since Sydney 2000, have been accompanied by leveraging programs (O'Brien and Chalip, 2007).

This fundamental shift from an event outcome to event leverage has provoked a growing body of literature to explore this phenomenon; the widely work held to date emphases on event leverage for the tourism and economic development (Roche et al., 2013). Chalip and associates (2003) suggest that the economic impact of major sports events relies primarily on two aspects: firstly, they can attract participants and spectators who bring money into the local economy; secondly, the events can enhance the destination's image through advertising and media coverage, thus helping to build visitation at other times of the year. To begin to understand this fairly new phenomenon; follow the model proposed by Chalip (2004) for economic leverage that visualizes a destination's portfolio of event as a 'leverageable resource' for both short and long-term outcomes (Figure 1). So, Chalip (2004) suggests in his model for short-term benefits that event marketers' goal is to 'optimize total trade and revenue' from the event through four means, which can be achieved by:

1. entice visitor spending;

2. lengthen visitor stays;

3. retain event expenditures; and

4. use the event to enhance regional business relationships.

Aimed at long-term benefits, Chalip (2004) proposes using the event media to 'enhance a host community's image', which is achievable through two strategies: 
5. showcasing the region through event advertising and reporting; and

6. using the event in regional advertising and promotions.

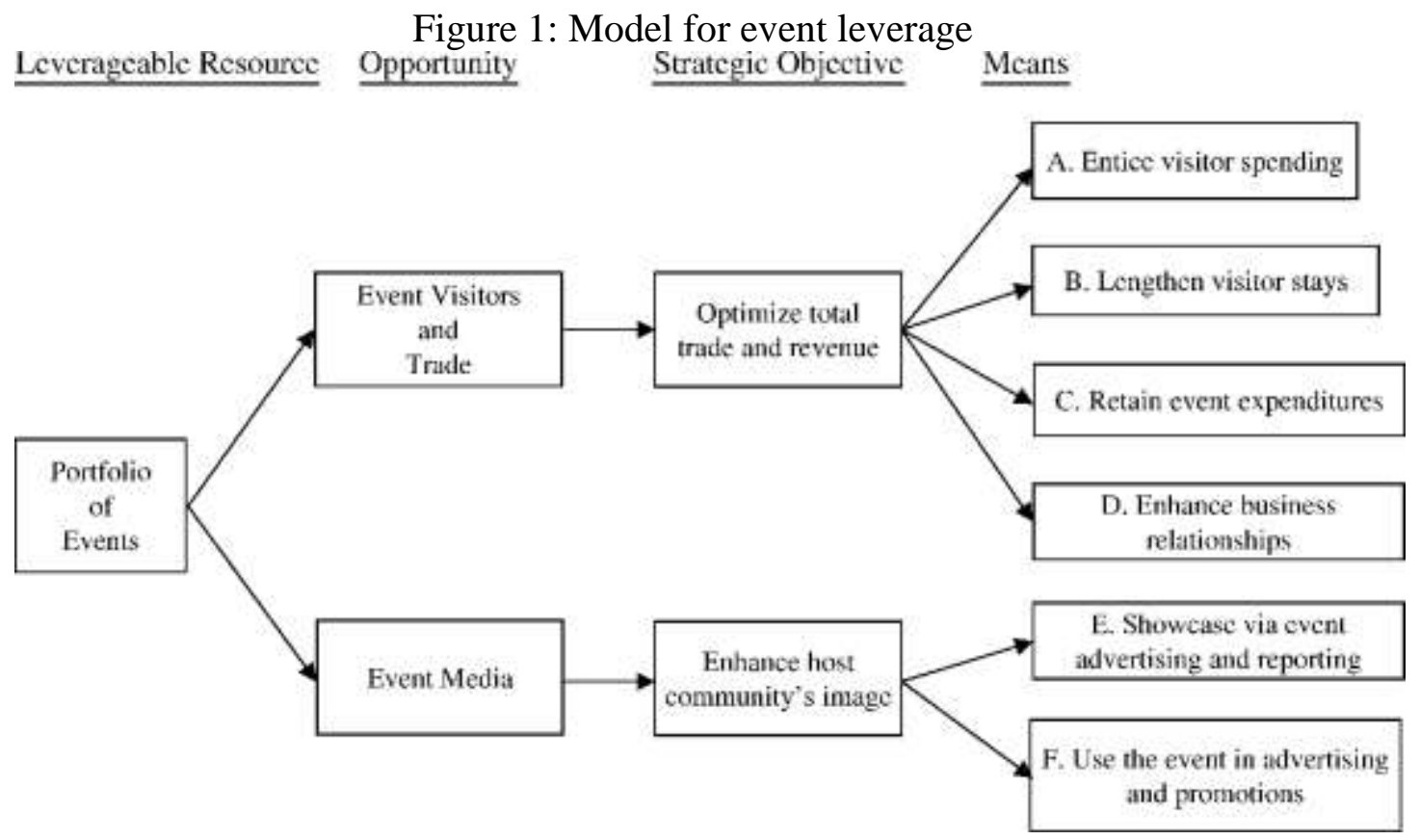

Source: Chalip's (2004).

O'Brien (2007) in a case study methodology put in examination Chalip's (2004) model for event leverage to study how the marketers of a local surfing festival created sustainable benefits for the hosting destination. His findings supported Chalip's (2004) model and illustrated also how the sport event was essential for the success of economic leveraging. Meanwhile, Green (2001) suggests that sport events can generate marketing benefits for destination promotion, lengthen visitors' stays and increase their potential spending patterns in the host destination (O'Brien and Chalip, 2007). Sport events can create possible networking opportunities for both the local and visiting corporate stakeholders, which lead to business relationships development and internal trade and investment beyond the event time (O'Brien, 2006; O'Brien and Gardiner, 2006). By sourcing all goods and services needed to run the sport event from the local suppliers, event expenditures remain in the host destination (O'Brien and Chalip, 2007). O'Brien (2007) demonstrates that the attractiveness of the sport event to the media provide competitive aspects and project desired destination images into key tourism markets. Obviously, the goal is to enhance the event's direct economic effects while also maintaining desirable image and business relationship opportunities for the host destination (O'Brien and Chalip, 2007).

Sport events can attract large spectators from country residents and tourists and create worldwide television exposure (Liu and Gratton, 2010) and generate revenues for the destination. Hence, the 2016 Summer' Olympics in Rio de Janeiro, Brazil provided approximately 5.2 billion television audience not including digital and social media, along with 356,924 hours of coverage across all platforms compared to 181,523 hours of coverage for London 2012; the largest ever for the Olympic Games (International Olympic Committee, December 2016). Six million tickets were available for sale and total revenues were estimated by $\$ 5.6$ billion which had increased by 6.2 percent compared with the 2012 revenues, the main reason of this increase is television broadcasting rights and marketing program (International Olympic Committee, July 2016). While, the 2014 FIFA World Cup 
in Brazil was watched by 3.2 billion television audience and an estimated 280 million people around the world watched matches online, with a total of 98000 hours were dedicated to its media coverage and a total of 3.4 million spectators at 64 matches, the highest recorded at any World Cup since USA 1994. Brazil received $\$ 7.2$ billion as a result of investments in the 2014 World Cup (FIFA, 2014).

Yet, there is a going debate among researchers about the effects of sport events, and some have even questioned whether there would be any effects at all (Chalip et al., 2003). Green and associates (2003) in their case analysis of exposure generated by the 2002 National Collegiate Athletic Association (NCAA) Women's Final Four basketball tournament in the United States of America; indicated that the event generated only insignificant coverage for the destination and the host city obtained few mentions throughout the media. Chalip and associates experimental research (2003) demonstrated that the event broadcast, event advertising and destination marketing often have a negative impact on spectators' perception of the destination's natural environment. Their study revealed also that there was a wider range of impacts in the long-haul market than in the short-haul market. Smith's $(2005,2006)$ empirical case studies regarding sport strategies adopted by three English cities suggested that, generally, sport events seemed to have established positive connotations amongst potential tourists. But the effect was still limited to only a small percentage of tourists; who were aware of the sport initiatives of those cities.

However, the importance of sport events for destinations is well documented at the South Africa International Summit on Tourism, Sport and Mega-events by the UNWTO in 2012, who states that at the time when some of the destinations are suffering from the impacts of recession, sports tourism will continue to grow (Presenza and Sheehan, 2013). Presenza and Sheehan (2013) try to build on the concept of using a portfolio of sport event to develop Termoli, an Adriatic destination in Southern Italy. The local government launched the project 'TermoliBike' in 2011, to promote a new tourism product 'bike tourism'. Their findings supported the concepts previously mentioned in related literature about increasing interest in the sport tourism and that sport events were important drivers of destination development. Dongfeng (2013) in his research explored the effects of a major sport event on the intentions of international tourists to revisit Shanghai, China. The study confirmed that the city has been relatively successful in reaching out to tourists by hosting major sport events and that the awareness of sport events had significant impact on the intention to revisit Shanghai.

\section{Sport events in Egypt}

Egypt would constitute a good sport arena for sport tourism. As, it has most of the essential elements required for sport tourism, such as: the climate, accommodation, proximity to some major tourists' markets, for example, the European countries and significant sport infrastructure which enable it to gain a fair share of sport tourism (Hussein, 2014). In the past decade, Egypt has hosted and organized some reputable championships. For instance, football is definitely considered the most favorite sport in Egypt. Lately, Egypt hosted the African Cup of Nations (CAN) in 2006 when the Egyptian national football team known as the 'Pharaohs' won the title. Egypt hosted the tournament three times before in 1959 when Egypt was known as the United Arab Republic, 1974 and 1986. Egypt is the most successful country in the cup's history, winning the competition a total of seven times, which includes three consecutive titles in 2006, 2008 and 2010 (Wood, 2014). Football tournament is not the only sport event hosted in Egypt. However, Egypt hosts also other championships.

Under the flag of 2016 Rio's Olympics, numerous competitions are held worldwide to choose the participating champs, in which Egypt hosts the African Handball Nations 
Championship, which is not only qualifying for the Olympics but also for the World Men's Handball Championship in France 2017. Egypt hosted the championship twice before in 2004 and 2010. Moreover, Egypt hosted the World Men's Handball Championship in 1999 and it is also expected to host the World Men's Handball Championship in 2021. Recently, Egypt won Egypt's International Handball Championship, organized by the Egyptian Handball Federation (EHF) in Cairo, which qualified the Egyptian national team for the African Handball Nations Championship (ElNadar, January 2016). However, handball is regarded as the second favorite sport in Egypt. On the other hand, Egypt hosted the Arab Juniors Basketball Championship in 2016, held in Alexandria, when Egypt's junior basketball team won. In addition, Egypt beat out Latvia, Italy and Israel, after it has been finally announced by the International Basketball Federation (FIBA) that the World Cup for juniors will be held in Cairo in 2017. Egypt will be the first African country to host the FIBA youth event (El-Nadar, September 2016). Basketball is supported by many Egyptians fans though.

1. Egypt hosts Men's World Team Squash Championships for the third time in 2015 instead of Kuwait, after it was suspended by the International Olympic Committee from hosting this event. Egypt hosted the tournament twice before in 1985 and 1999. It is worth to mention that the competition is played every two years and organized by the World Squash Federation (Abd El Rasoul, 2015). Egypt hosted the 2016 International Billiards and Snooker Federation (IBSF) World Six Reds and Team Snooker Championship, which was held in Sharm El-Sheikh. It was attended by international participants and spectators from 27 countries (Pathak, 2016). Besides, Egypt organizes the World Shooting Sport Championship 2016 in Cairo for the second time respectively (Moamar, 2015).

2. In order to enhance tourism the Ministry of Sports and Youth Affairs in cooperation with the Ministry of Tourism organized a number of international championships on Egyptian grounds especially in great tourism destinations, such as Sharm El-Sheikh and Hurghada. This included the Triathlon African Cup and Pan Arab Championships, organized by Alameda Triathlons and the Arab Triathlon Confederation, which was held in Sharm El-Sheikh earlier 2016; El-Gouna International Squash Open held in ElGouna in April 2016 and re-launching of Al-Ahram Squash Open at the Giza Pyramids after 10 years of suspension. Moreover, the Ministry of Sports and Youth Affairs will support all international sport events to promote tourism in Egypt. An example of such prestigious events include the 2016 PSA Men's World Squash Open Championship and PSA Women's International Squash Open Championship which is organized by Wadi Degla Club for the first time in the history of the championship that the Professional Squash Association (PSA) has allowed a club to organize it, rather than a federation or an association. In addition, the Heliopolis Sporting Club (HSC) hosted the $24^{\text {th }}$ edition of the Heliopolis International Water Polo and Synchronized Swimming Tournament in 2015. During the tournament, the HSC organized two days cultural tour of Cairo for the Serbian, Hungarian, German, Greek, and Russian athletes (El-Nadar, April 2016, October 2016). This would be considered as a kind of event leverage.

3. This quick overview of some of the major sport events hosted in Egypt showed that Egypt has the capabilities that allow it to compete strongly with other countries in hosting as well as organizing sport events. Moreover, most of the above mentioned events are hosted in Egypt's greatest tourists' attractions which would allow for leverage program. However, there are some problems that may hinder the demand for sport tourism in Egypt and affect the sport events attendances' numbers, for instance, the occurrence of political tension and terrorism attacks that target crowded areas 
where it is more difficult to secure and most of the sport events are held in large areas where a lot of spectators attend. Moreover, the lack of appropriate infrastructure to accommodate major sport events, poor condition of local transportation (Hussein, 2014), and traffic congestions especially in major cities such as: Alexandria and Cairo.

\section{Methodology}

\section{Research instrument}

To carry on with this research a questionnaire was developed which contained two sections: the first included socio- demographic and general questions such as: gender, age, education, country of origin and number of visiting times to Egypt. This section included also questions about tourists' intention to visit Egypt for sport tourism in the next five years. An open-ended question examining tourists' ability to recall some of the sport events that Egypt hosted in the past decade was part of this section. It was required to better understand what types of sport events are more attractive to tourists. This question was followed by an additional question considering means of knowledge of such events.

The second section contained 16 factors that influence tourists' intentions to visit Egypt for sport tourism. These factors were measured using a five-point Likert scale ranging from $1=$ 'strongly disagree' to $5=$ 'strongly agree'. The factors were selected after a comprehensive review of sport tourism literature which was found in the study of Dongfeng (2013) and Roche and associates (2013). So the most relevant factors to the research objectives were adapted. Prior to the formal survey, various faculty members and experts in the field of tourism and sports were consulted for revising relevance and clarity of the questions. A pilot test was conducted also among 10 international tourists to modify any ambiguous or misleading questions. This procedure provided valuable information about the questionnaire design, wording and measurement scales.

\section{Sampling and data collection}

The study population consisted of international tourists whose primary purpose was not attending sport events in Egypt. The research survey was conducted during the month of February 2017; at the four most visited tourist attractions in the major two cities in Egypt; Alexandria and Cairo (i.e., the Alexandria National Museum, the Bibliotheca Alexandrina, the Egyptian Museum of Antiquities and the Pyramids).

The data was collected through self-completion structured questionnaire. It took five minutes to complete in average. Respondents were selected after asking them a filter question to identify non- sport tourists. There was no problem in completing the questionnaire as most of the respondents understand English (the original language of the questionnaire). It was aimed to collect 400 questionnaires, but in total, only 347 completed questionnaires were obtained with response rate of $87 \%$. In total 340 questionnaires were usable for analysis as seven of them were incomplete.

\section{Data analysis}

Statistical analysis was completed using Statistical Package for Social Sciences (SPSS/version 20) software. The characteristics of the respondents' socio- demographic data and general questions were presented using frequency and percentage distributions. The open-ended question responses have been recorded into categories and a frequency analysis was undertaken. Regarding the factors that influence tourists' intentions to visit Egypt for sport tourism, mean and standard deviation was calculated. In respect of, the difference between independent variables and questionnaire items whether it is meaningful to analyze; the one-way analysis of variance (ANOVA) and t-test were applied. Regression analysis was conducted to predict the effect of the different factors that influence tourists' 
intentions to visit Egypt for sport tourism. Significance of the obtained results was judged at the 5\% level. Reliability analysis of the questionnaire items revealed that Cronbach's alpha values ranged between 0.89 and 0.93 ; in total average was 0.91. Consequently, the questionnaire has considerable reliability (Kaiser, 1974; Nunnally, 1978).

\section{Findings and discussion}

\section{Respondents' profile}

Table 1 demonstrates the socio- demographic information of the respondents. Just over half of the respondents were male $(55.6 \%)$ and $44.4 \%$ were female. Under half $(45.6 \%)$ of the respondents aged between 18 and 29, 26.7\% were between 30 and 39 years, $15.9 \%$ were between 50 and 59 years, while the remainders (11.8\%) were above 60 years old or aged between 40 and 49 . More than half $(57.9 \%)$ of the respondents were post graduate, $27.9 \%$ completed college and $14.2 \%$ finished high school. More than half $(59.7 \%)$ of the respondents were from short-haul markets (i.e. neighbour countries from Europe, Africa and Middle East) and 40.3\% were from long-haul markets (i.e. other countries). Almost three quarters $(72.6 \%)$ of the respondents visited Egypt once and the remaining quarter (27.4\%) had visited Egypt before.

Table 1: Respondents' socio- demographic information

\begin{tabular}{|c|c|c|}
\hline & Frequency & Percent \\
\hline \multicolumn{3}{|l|}{ Gender } \\
\hline Male & 189 & 55.6 \\
\hline Female & 151 & 44.4 \\
\hline \multicolumn{3}{|l|}{ Age } \\
\hline 18-29 years & 155 & 45.6 \\
\hline $30-39$ years & 91 & 26.7 \\
\hline 40-49 years & 8 & 2.4 \\
\hline $50-59$ years & 54 & 15.9 \\
\hline 60 years or more & 32 & 9.4 \\
\hline \multicolumn{3}{|l|}{ Education } \\
\hline High School & 48 & 14.2 \\
\hline College & 95 & 27.9 \\
\hline Post-Graduate & 197 & 57.9 \\
\hline \multicolumn{3}{|l|}{ Country of origin } \\
\hline Short-Haul Market & 203 & 59.7 \\
\hline Long-haul Market & 137 & 40.3 \\
\hline \multicolumn{3}{|c|}{ Number of times visited Egypt } \\
\hline First time visit & 247 & 72.6 \\
\hline Repeated visitation & 93 & 27.4 \\
\hline
\end{tabular}

\section{Types of sport events attractive to tourists}

Table 2 summarizes respondents' interest of sport events in Egypt. Over half (52.9\%) of the respondents did not recall any sport events in Egypt. Among the sport events recalled; football or soccer (depending how it is known in country of origin) was the most recalled (30.9\%), followed by champions $(13.3 \%)$ and teams $(2.9 \%)$. This is mainly due to the timing of the survey; as it was conducted just after the African Cup of Nations (CAN) in early 2017, where Egypt football team known as the 'Pharaohs' won the second place and many of its champions were famous. When the respondents were asked how they knew about those events recalled. Just under half $(39.8 \%)$ of the respondents choose internet, followed by mass media $27 \%$, then friends or relatives $10.5 \%$, events news reports and 
advertisements $8.6 \%$ and tourism brochures and guidebooks $5.5 \%$. The results had recognized the important role of internet and mass media in sport events covering, in addition to the word of mouth in creating awareness of such events. This was followed by a question where the respondents were asked whether they would visit Egypt to attend sport events. More than half $(58.8 \%)$ of the respondents were not sure, while the remainder were almost equally divided between yes $22.9 \%$ and no $18.3 \%$. In answering RQ1; the results indicated that football was the most attractive sport event as Egyptian football has a good reputation among respondents.

Table 2: Respondents' interest in sport events in Egypt

\begin{tabular}{|c|c|c|}
\hline & Frequency & Percent \\
\hline \multicolumn{3}{|l|}{ Sport events recalled in Egypt } \\
\hline Football/ Soccer & 105 & 30.9 \\
\hline Teams & 10 & 2.9 \\
\hline Champions & 45 & 13.3 \\
\hline None & 180 & 52.9 \\
\hline \multicolumn{3}{|c|}{ Means of knowledge about the sport events recalled in Egypt* } \\
\hline Mass Media & 141 & 27 \\
\hline Events news reports & 45 & 8.6 \\
\hline Internet & 208 & 39.8 \\
\hline Events advertisements & 45 & 8.6 \\
\hline Friends or relatives & 55 & 10.5 \\
\hline Tourism brochures and guidebooks & 29 & 5.5 \\
\hline \multicolumn{3}{|c|}{ Likeliness to visit Egypt to attend sport events } \\
\hline Yes & 78 & 22.9 \\
\hline No & 62 & 18.3 \\
\hline May be & 200 & 58.8 \\
\hline
\end{tabular}

\section{Factors influencing tourists' intentions to visit Egypt for sport tourism}

Table 3 examines the different factors that influence tourists' intentions to visit Egypt for sport tourism. In total 16 factors were assorted into three main categories entitled 'destination attractiveness' (five factors), 'tourism facilities' (five factors) and 'sport events attributes' (six factors). The mean scores $(M)$ and standard deviations (S.D.) of the 16 factors were calculated. The scores ranged between $(M=4.35$, S.D. $=0.59)$ and $(M=3.56$, S.D. $=0.84)$.

Table 3: Factors influencing tourists' intentions to visit Egypt for sport tourism

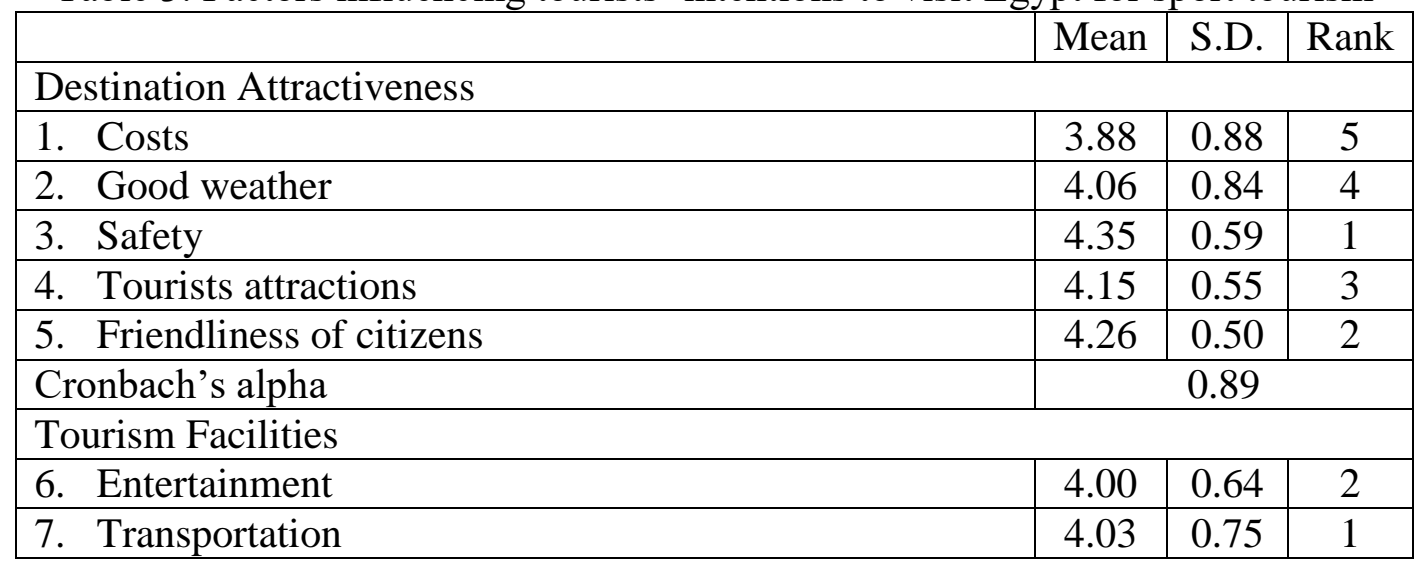




\begin{tabular}{|l|c|c|c|}
\hline 8. Quality of accommodation & 3.94 & 0.77 & 4 \\
\hline 9. Quality of food & 3.97 & 0.75 & 3 \\
\hline 10. Accessibility to sports venue & 3.71 & 0.62 & 5 \\
\hline Cronbach's alpha & \multicolumn{3}{|c|}{0.93} \\
\hline Sport Events Attributes & 3.74 & 0.78 & 2 \\
\hline 11. Quality of sports venue & 3.76 & 0.69 & 1 \\
\hline 12. Availability of sport-related activities/attractions & 3.38 & 0.84 & 6 \\
\hline 13. Sport events attendance size & 3.41 & 0.98 & 5 \\
\hline 14. Amount of sport events offered in a destination & 3.62 & 0.84 & 4 \\
\hline 15. Type of sport events held in a destination & 3.65 & 0.97 & 3 \\
\hline 16. Marketing and promotion efforts & \multicolumn{3}{|c|}{0.90} \\
\hline Cronbach's alpha & \multicolumn{3}{|l}{} \\
\hline
\end{tabular}

To answer RQ2; the results indicated that the most important factors influencing tourists' intentions to visit Egypt for sport tourism were safety, friendliness of citizens, tourists attractions, good weather, transportation, entertainment, quality of food and accommodation, costs, and availability of sport-related activities and attractions (Figure 1). Safety came first in tourists' priorities because many of sport events include a large number of audiences where personal safety is important. Safety is much valued by sports events attendees (Mohan, 2010). It could be realized that sport tourist are more concerned when it comes to safety majors; as most of the sport events are held outdoors or in places where it is difficult to secure (Roche et al., 2013). Friendliness of citizens was also found to be a significant influence for tourists, but even more for sport tourists who want the locals to be friendly (Chen and Funk, 2010). Travelling to attend sport event did not depend only on sport- related activities and attractions, but also the availability of other tourists' attractions and entertainment, which are also considered as an effective way to encourage tourists to increase spending and enhance tourists' experiences (Smith and Stewart, 2007).

A good Weather was a significant influence on sport tourists' choice to visit a destination to attend a sport event; especially most of the sport events are held outdoors (Hansen and Gauthier, 1989). Speed and ease in transportation and availability of public transportation, was confirmed also in other researches to be an influence of destination choice for sport tourism (Roche et al., 2013). Both the quality of food and accommodation were an important influence on intention to visit a destination for sport events (Chen and Funk, 2010). The quality of food includes number of various dinning places and ethnic food. While, the quality of accommodation includes room size, cleanliness and amenities and facilities available such as restaurants and swimming pools. Various costs for products such as travel, accommodation, food and event ticket price were important influence on destination choice for sport tourism (Hansen and Gauthier, 1989). More recently, Mohan (2010) found that the cost of accommodation is one of the strongest influences on the decision to travel to a sport event. 
Figure 1: Top 10 factors influencing tourists intentions to visit Egypt for sport tourism

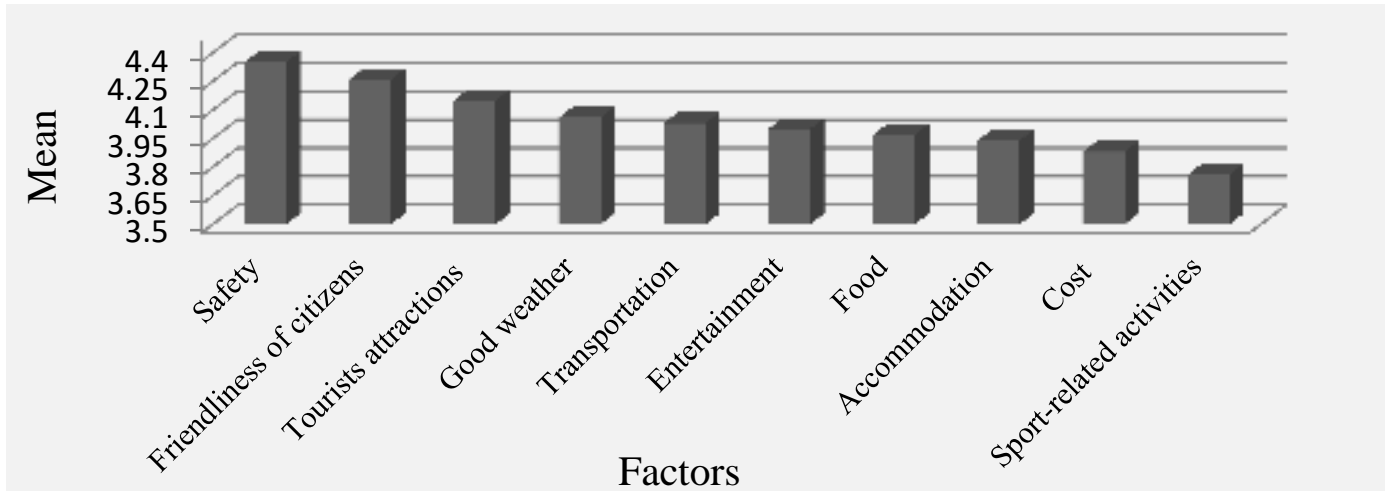

Other important factors that influence tourists' intentions to visit Egypt for sport tourism included: quality and accessibility to sports venue, marketing and promotion efforts, type and amount of sport events held in a destination and sport events attendance size. For sure the quality of the sports venue (i.e. cleanliness, comfortable seats, sound system, etc..), in addition to the ease to travel to the venue and availability of parking lots were among the important factor influencing tourists intentions to visit a destination, as affirmed by Hansen and Gauthier (1989) and Roche and associates (2013). Earlier studies for example the study of Chalip and Leyns (2002) had illustrated that more revenues were generated from sport events that used targeted promotions and event marketing efforts to attract event/sport visitors. The type and amount of sport events held in a destination had also a significant influence on tourists' intentions to visit a destination to attend these events, with some indication to sport events attendance number as some sport events are being attended by more spectator than others (Gratton et al., 2005).

The importance behind the previous listing of factors influencing tourists' intentions to visit Egypt for sport tourism is that, the more tourists who know about a destination's attractions, the more likely it is to be visited in the future by first time and return visitors (Garnham, 1996). It is worth mentioning also that Chen and Funk (2010) found many similarities between factors influencing tourists' intentions to visit a destination for sport tourism or any other type of tourism. However, Shonk and Chelladurai (2008, p. 596) noted that 'in the case of sport tourism, success is an attribute of satisfied customers who intend to return to both the sporting event and the destination'. So, all marketing efforts undertaken to target sport tourists would be probably targeting non-sport tourists also.

All different factors were computed into a multiple regression analysis to predict intention to visit Egypt to attend sport events within the next five years. The results (Table 4) indicated that the three factors categories were significantly ( $\mathrm{R}$ Square=.290, $F=45.730$, Sig.=.0001) predictive of the intention to visit Egypt to attend sport events. Hence, the findings were aligned with prior researches such as Dongfeng (2013), where it was found that all three factors were significant contributors to the prediction. 
Table 4: Regression analysis of different factors that affect visiting Egypt to attend sport events

\begin{tabular}{|l|c|c|c|c|c|}
\hline \multicolumn{1}{|c|}{ Coefficients $^{\mathrm{a}}$} \\
& \multicolumn{2}{|c|}{$\begin{array}{c}\text { Unstandardized } \\
\text { Coefficients }\end{array}$} & $\begin{array}{c}\text { Standardized } \\
\text { Coefficients }\end{array}$ & T & Sig. \\
\cline { 2 - 6 } & $\mathrm{B}$ & Std. Error & Beta & & \\
\hline (Constant) & 5.347 & .565 & & 9.470 & $.0001^{*}$ \\
\cline { 2 - 6 } $\begin{array}{l}\text { Destination Attractiveness } \\
\text { Tourism Facilities }\end{array}$ & .413 & .094 & .209 & 4.377 & $.0001^{*}$ \\
\cline { 2 - 6 } Sport Events Attributes & $-.747-$ & .138 & $-.277-$ & $-5.424-$ & $.0001^{*}$ \\
\cline { 2 - 7 } & $-.485-$ & .068 & $-.352-$ & $-7.086-$ & $.0001^{*}$ \\
\hline
\end{tabular}

a. Dependent Variable: 3

$\mathrm{R}^{2}=.290, \mathrm{~F}=45.730$, Sig. $=.0001 *$

\section{Socio-demographic variables impact on tourists' intentions to visit Egypt for sport tourism}

In an attempt to answer RQ3; the one-way analysis of variance (ANOVA) and t-test were applied to examine the relation between the socio- demographics characteristics and factors that influence tourists' intention to visit Egypt. The results revealed that the respondents' country of origin or previous visits to Egypt were not significant. However, the results illustrated also that the respondents' gender, age and education level had a significant impact on tourists' intention to visit Egypt. Thus, the results supported prior study by Dongfeng (2013), who found that there were no significant differences based on country of origin or visiting times, while a significant difference was found between genders only.

Table 5 shows that gender had a significant impact on tourists' intention to visit Egypt at level .0001 in favor to male regarding tourism facilities and sport events. The scores ranged between $(M=4.07$, S.D. $=0.29)$ and $(M=3.76$, S.D.=0.59). The male respondents were more interested in the sport events and the availability of tourism facilities rather than destination attractiveness.

Table 5: Relation between different factors that influence tourists' intentions to visit Egypt for sport tourism and gender

\begin{tabular}{|c|c|c|c|c|c|}
\hline & & Mean & S.D. & t-test & $\mathrm{P}$ \\
\hline \multirow{2}{*}{$\begin{array}{l}\text { Destination } \\
\text { Attractiveness }\end{array}$} & Male & 4.13 & 0.36 & \multirow{2}{*}{1.117} & \multirow{2}{*}{.291} \\
\hline & Female & 4.17 & 0.46 & & \\
\hline \multirow{2}{*}{ Tourism Facilities } & Male & 4.07 & 0.29 & \multirow{2}{*}{67.693} & \multirow{2}{*}{$.0001 *$} \\
\hline & Female & 3.82 & 0.26 & & \\
\hline \multirow{2}{*}{ Sport Events Attributes } & Male & 3.76 & 0.59 & \multirow{2}{*}{23.938} & \multirow{2}{*}{$.0001^{*}$} \\
\hline & Female & 3.46 & 0.54 & & \\
\hline
\end{tabular}

The results revealed also that the respondents' age had a significant impact on tourists' intention to visit Egypt at level ranged between .0001 and .021 in favor to respondents aged between 18 and 29 (Table 6). The scores ranged between $(M=4.28$, S.D. $=0.42)$ and $(M=3.80$, S.D. $=0.00)$. It is obvious that the youth and younger people are more active and admire sport events. In addition to their likeliness of visiting new places, that is significantly important in case of leveraging of sport events for supporting tourism. 
Table 6: Relation between different factors that influence tourists' intentions to visit Egypt for sport tourism and age

\begin{tabular}{|c|c|c|c|c|c|}
\hline & & Mean & S.D. & $\mathrm{F}$ & $\mathrm{P}$ \\
\hline \multirow{5}{*}{$\begin{array}{l}\text { Destination } \\
\text { Attractiveness }\end{array}$} & 18-29 years & 4.28 & 0.42 & \multirow{5}{*}{2.929} & \multirow{5}{*}{$.021 *$} \\
\hline & 30-39 years & 4.27 & 0.09 & & \\
\hline & 40-49 years & 4.10 & 0.48 & & \\
\hline & 50-59 years & 4.13 & 0.31 & & \\
\hline & 60 years or more & 4.00 & 0.00 & & \\
\hline \multirow{5}{*}{$\begin{array}{l}\text { Tourism } \\
\text { Facilities }\end{array}$} & 18-29 years & 4.12 & 0.35 & \multirow{5}{*}{12.100} & \multirow{5}{*}{$.0001 *$} \\
\hline & $30-39$ years & 3.95 & 0.31 & & \\
\hline & $40-49$ years & 3.87 & 0.23 & & \\
\hline & 50-59 years & 3.60 & 0.00 & & \\
\hline & 60 years or more & 3.80 & 0.17 & & \\
\hline \multirow{5}{*}{$\begin{array}{l}\text { Sport Events } \\
\text { Attributes }\end{array}$} & 18-29 years & 3.80 & 0.00 & \multirow{5}{*}{8.678} & \multirow{5}{*}{$.0001 *$} \\
\hline & 30-39 years & 3.74 & 0.59 & & \\
\hline & 40-49 years & 3.62 & 0.25 & & \\
\hline & $50-59$ years & 3.58 & 0.66 & & \\
\hline & 60 years or more & 3.07 & 0.09 & & \\
\hline
\end{tabular}

The results indicated that the respondents' education level had a significant impact on tourists' intention to visit Egypt at level ranged between .0001 and .021 in favor to post graduate respondents regarding tourism facilities and sport events attributes (Table 7). The scores ranged between $(M=3.99$, S.D. $=0.28)$ and $(M=3.69$, S.D. $=0.61)$. The higher level of education the more people interested in active style of life for the sake of their general health. In addition to their wide knowledge of destination which is owed to their education.

Table 7: Relation between different factors that influence tourists' intentions to visit Egypt for sport tourism and education

\begin{tabular}{|c|c|c|c|c|c|}
\hline & & Mean & S.D. & $\mathrm{F}$ & $\mathrm{P}$ \\
\hline Destination & Secondary School & 4.15 & 0.17 & \multirow{3}{*}{.986} & \multirow{3}{*}{.374} \\
\hline \multirow[t]{2}{*}{ Attractiveness } & College & 4.10 & 0.35 & & \\
\hline & Post-Graduate & 4.17 & 0.46 & & \\
\hline \multirow{3}{*}{ Tourism Facilities } & Secondary School & 3.75 & 0.17 & \multirow{3}{*}{2.605} & \multirow{3}{*}{$.021 *$} \\
\hline & College & 3.94 & 0.36 & & \\
\hline & Post-Graduate & 3.99 & 0.28 & & \\
\hline \multirow{3}{*}{$\begin{array}{l}\text { Sport Events } \\
\text { Attributes }\end{array}$} & Secondary School & 3.20 & 0.48 & \multirow{3}{*}{12.930} & \multirow{3}{*}{$.0001 *$} \\
\hline & College & 3.55 & 0.49 & & \\
\hline & Post-Graduate & 3.69 & 0.61 & & \\
\hline
\end{tabular}

\section{Conclusion}

This study confirmed what other literature had discussed of the importance of leveraging of sport events to support tourism and enhance economic development. Sport events are now an important component in tourism development due to the increasing interest in attending sport events.

The results revealed the interest of tourists in sport events in Egypt especially football which was the most attractive type of sport due to its good reputation. The empirical results identified some key factors that influence tourists intentions to visit Egypt for sport tourism, where safety came first, followed by, friendliness of citizens, availability of tourists attractions, good weather, ease in transportation, availability of entertainment, then, quality of food and accommodation, costs of travel and event ticket price and last but 
not least availability of sport-related activities and attractions. The results had identified also that young post graduate male aged between 18 and 29 years were more interested in visiting Egypt for sport tourism than others.

There are a couple of practical implications that can be drawn from this research. Firstly, the ability to identify target segments, thus, offering a good chance to better implement marketing plans among tourism markets. Secondly, the knowledge of the factors influencing tourists' intentions to visit Egypt for sport tourism, so, marketers should improve their understanding of those factors to better management for the sake of increasing tourists' numbers, profits and economic benefits, and creating positive word-ofmouth through increasing tourists' satisfaction.

4. In conclusion, the research highlighted the impacts of hosting sport events on the destination development, awareness and visitation intention. The research revealed also the potentials that sport events would offer to support tourism in Egypt. The research showed also that Egypt has the capabilities that allow it to compete strongly with other countries in both hosting and organizing sport events, as well as applying leverage programs to support tourism. However, security issues must be treated as soon as possible especially those related to political instability and terrorism, because it would hinder sport tourism in Egypt.

\section{Future research}

Future researches must be conducted to further validate the results of this study. In addition, comparative studies should be undertaken between sport tourists and non-sport tourists regarding the intentions to re-visit a destination after attending sport events. Future researches may also examine whether there are difference among factors depending on the type of sport events or destinations. The economic impacts of such events on a destination should be investigated also.

\section{References}

Abd El Rasoul, A. (3 November 2015). Egypt to host World Squash Championships for the third time. Ahramonline. Available at: http://english.ahram.org.eg/NewsContent/6/56/162579/Sports/Omni-Sports/Egyptto-host-World-Squash-Championships-for-the-t.aspx (Accessed 5 February 2017).

Avraham, E. (2014). Hosting Events as a Tool for Restoring Destination Image. International Journal of Event Management Research, 8(1):61-67.

Avraham, E. and Ketter, E. (2013). Marketing destinations with prolonged negative images: Towards a new model. Tourism Geographies, 15(1):145-164.

Beirman, D. (2003). Restoring tourism destinations in crisis. Cambridge, UK: CABI.

Chalip, L. (2004). Beyond impact: a general model for host community event leverage. In Ritchie, B. and Adair, D. (Eds), Sport Tourism: Interrelationships, Impacts and Issues, Clevedon: Channel View.

Chalip, L. (2007). Towards social leverage of sport events. Journal of Sport and Tourism, 11(2):1-19.

Chalip, L., Green, B. and Hill, B. (2003). Effects of sport event media on destination image and intention to visit. Journal of Sport Management, 17:214-234.

Chalip, L. and Leyns, A. (2002). Local business leveraging of a sport event: managing an event for economic benefit. Journal of Sport Management, 16(2):132-158.

Chen, N. and Funk, D. (2010). Exploring destination image, experience and revisit intention: a comparison of sport and non-sport tourist perceptions. Journal of Sport and Tourism, 1(5-3): 239-259. 
Deccio, C. and Baloglu, S. (2002). Non host community resident reactions to the 2002 Winter Olympics: the spillover impacts. Journal of Travel Research, 41(1):46-56.

Deery, M., Jago, L. and Fredline, L. (2004). Sport tourism or event tourism: Are they one and the same? Journal of Sport Tourism, 9(3):235-245.

Delpy, L. (1998). An overview of sport tourism: building towards a dimensional framework. Journal of Vacation Marketing, 4(1):23-38.

Dimanche, F. (2003). The role of sports events in destination marketing. In Keller, P. and Bieger, T. (Eds.), Sport and Tourism (pp. 303-311). Proceedings of the 53rd. AIEST congress, St Gallen, Switzerland: AIEST.

Dongfeng, L. (2013). Major sports events, destination image and intention to revisit from the foreign tourist's perspective. International Journal of Sports Marketing and Sponsorship, April 2013:23-34.

El-Nadar, M. (13 April 2016). Sports may be the path to boosting tourism in Egypt. Daily News Egypt. Available at: http://www.dailynewsegypt.com/2016/04/13/sportsmay-path-boosting-tourism-egypt/ (Accessed 5 February 2017).

El-Nadar, M. (13 January 2016). Egypt hosts 2016 African Handball Nations Championship qualifying for Olympics. Daily News Egypt. Available at: http://www.dailynewsegypt.com/2016/01/13/egypt-hosts-2016-african-handballnations-championship-qualifying-for-olympics/ (Accessed 5 February 2017).

El-Nadar, M. (25 September 2016). Egyptian junior basketball team wins Arab Championship, comes 2nd in African Championship. Daily News Egypt. Available at: http://www.dailynewsegypt.com/2016/09/25/egyptian-junior-basketball-teamwins-arab-championship-comes-2nd-african-championship/ (Accessed 5 February 2017).

El-Nadar, M. (26 October 2016). International championships a key pillar for attracting tourism to Egypt: Sports Minister. Daily News Egypt. Available at: http://www.dailynewsegypt.com/2016/10/26/international-championships-keypillar-attracting-tourism-egypt-sports-minister/ (Accessed 5 February 2017).

FIFA (2014). The 2014 FIFA World Cup in Numbers. Available at: http://resources.fifa.com/mm/document/tournament/competition/02/44/29/89/fifaw orldcupinnumbers_120714_v7_eng_neutral.pdf (Accessed 1 February 2017).

Fullerton, S. and Mertz, G. (2008). The four domains of sports marketing: a conceptual framework. Sport Marketing Quarterly, 17(2):90-108.

Getz, D. (1997). Event Management and Event Tourism. New York, NY: Cognizant.

Getz, D. (2003). Sport event tourism: Planning, development, and marketing. In Hudson, S. (Ed.), Sport and adventure tourism (pp. 49-85). New York: Haworth Hospitality Press.

Gibson, H. (1998). Active sport tourism: who participates? Leisure Studies, 17(2):155170.

Gibson, H., Kaplanidou, K. and Jin Kang, S. (2012). Small-scale event sport tourism: A case study in sustainable tourism. Sport Management Review, 15:160-170.

Gibson, H., Willming, C. and Holdnak, A. (2003). Small-scale event sport tourism: fans as tourists. Tourism Management, 24:181-190.

Gratton, C., Dobson, N. and Shibli, S. (2000). The economic importance of major sports events: A case study of six events. Managing Leisure, 5:17-28.

Gratton, C., Shibli, S. and Coleman, R. (2005). Sport and economic regeneration in cities. Urban Studies, 42(5/6):985-999.

Garnham, B. (1996). Ranfurly shield rugby: an investigation into the impacts of a sporting event on a provincial city, the case of New Plymouth, Taranaki, New Zealand. Festival Management and Event Tourism, 4(3-4):145-149. 
Green, B. (2001). Leveraging subculture and identity to promote sport events. Sport Management Review, 4:1-20.

Green, B. and Chalip, L. (1998). Sport tourism as the celebration of subculture. Annals of Tourism, 25(2): 275-291.

Green, B., Costa, C. and Fitzgerald, M. (2003). Marketing the host city: analyzing exposure generated by a sport event. International Journal of Sports Marketing and Sponsorship, 4: 335-353.

Hansen, H. and Gauthier, R. (1989). Factors affecting attendance at professional fan events. Journal of Sport Management, 3(1):15-32.

Higham, J. (1999). Commentary-sport as an avenue of tourism development: An analysis of the positive and negative impacts of sport tourism. Current Issues in Tourism, 2(1):82-90.

Honaria, H., Goudarzib, M., Heidaric, A. and Emamid, A. (2010). A comparison of the viewpoints of tourists, interested managers and cultural heritage organization managers regarding sport tourism-driven job and income creation in MazandaranIran. Procedia Social and Behavioral Sciences, 2:5659-5663.

Hussein, M. (2014). Sport tourism in Egypt Opportunities and Challenges. Journal of Tourism and Hospitality Management, 2(2):53-64.

International Olympic Committee (December 2016). Global Broadcast and Audience Report: Olympic Games Rio 2016. Available at: https://stillmed.olympic.org/media/Document\%20Library/OlympicOrg/Games/Su mmer-Games/Games-Rio-2016-Olympic-Games/Media-Guide-for-Rio2016/Global-Broadcast-and-Audience-Report-Rio2016.pdf\#_ga=1.244392003.736295039.1485947704 (Accessed 1 February 2017).

International Olympic Committee (July 2016). IOC Marketing: Media Guide: Olympic Games Rio $2016 . \quad$ Available at: https://stillmed.olympic.org/media/Document\%20Library/OlympicOrg/Games/Su mmer-Games/Games-Rio-2016-Olympic-Games/Media-Guide-for-Rio-2016/IOCMarketing-Media-Guide-Rio-2016.pdf\#_ga=1.244392003.736295039.1485947704 (Accessed 1 February 2017).

Jiménez-Naranjo, H., Coca-Pérez, J., Gutiérrez-Fernández, M. and Sánchez-Escobedo, M. (2016). Cost-benefit analysis of sport events: The case of World Paddle Tour European. Research on Management and Business Economics, 22:131-138.

Kaiser, H. (1974). An index of factorial simplicity. Psychometrika, 39, 31-36.

Kim, W. and Walker, M. (2012). Measuring the social impacts associated with Super Bowl XLIII: preliminary development of a psychic income scale. Sport Management Review, 15:91-108.

Kim, W., Mun Jun, H., Walker, M. and Drane, D. (2015). Evaluating the perceived social impacts of hosting large-scale sport tourism events: Scale development and validation. Tourism Management, 48:21-32.

Konstantaki, M. and Wickens, E. (2010). Residents' perception of environmental and security issues at the 2012 London Olympic Games. Journal of Sport and Tourism, 15(4): 337-357.

Kurtzman, J. and Zauhar, J. (2003). A wave in time: the sport tourism phenomenon. Journal of Sport Tourism, 8(1):35-47.

Kurtzman, J. and Zauhar, J. (2005). Sports tourism consumer motivation. Journal of Sport Tourism, 10(1):21-31.

Liu, D. and Gratton, C. (2010). The impact of mega sporting events on live spectators' images of a host city: a case study of the Shanghai F1 Grand Prix. Tourism Economics, 16(3):629-645. 
Marris, T. (1987). The role and impact of mega-events and attractions on regional and national tourism development: resolutions of the 37th Congress of the AIEST. Calgary Revue de Tourism, 42(4):3-12.

Moamar, A. (1 December 2015). Egypt to organize the World Shooting Sport Championship 2016. Sada ElBalad. Available at: http://www.elbalad.news/1433883 (Accessed 5 February 2017).

Mohan, L. (2010). Effect of destination image on attendance at sporting events. Tourism and Hospitality Research, 10(3):157-170.

Nunnally, J. (1978). Psychometric Theory. New York: McGraw-Hill.

O'Brien, D. (2007). Points of leverage: maximizing host community benefit from a regional surfing festival. European Sport Management Quarterly, 7 (2).

O'Brien, D. and Chalip, L. (2007). Executive training exercise in sport event leverage. International Journal of Culture, Tourism and Hospitality Research, 1(4):296-304.

O'Brien, D. and Chalip, L. (2008). Sport events and strategic leveraging: pushing towards the triple bottom line. In Woodside, A. and Martin, D. (Eds), Tourism management: analysis, behaviour and strategy, Cambridge, MA: CABI Publishing.

O'Brien, D. and Gardiner, S. (2006). Creating sustainable mega-event impacts: networking and relationship development through pre-event training. Sport Management Review, 9: 25-48.

Papanikos, G. (2015). The Economic Effects of a Marathon as a Sport Tourism Event. Athens Journal of Sports, 2(4):225-240.

Pathak, V. (2 April 2016). Tournament Info: 2016 IBSF World Team and 6Reds. Available at:http://ibsf.info/index.php?option=com_k2\&view=item\&id=475\%3Atournamentinfo-2016-ibsf-world-team-6reds\&Itemid=182 (Accessed 5 February 2017).

Pranić, L., Petrić, L. and Cetinić, L. (2012). Host population perceptions of the social impacts of sport tourism events in transition countries. International Journal of Event and Festival Management, 3(3):236-256.

Presenza. A. and Sheehan, L. (2013). Planning tourism through sporting events. International Journal of Event and Festival Management, 4(2):125-139.

Priestley, G. (1995). Sports tourism: the case of golf. In Ashworth, G. and Dietvorst, A. (Eds), Tourism and Spatial Transformations: Implications for Policy and Planning, Wallingford: CAB International, pp. 205-223.

Ritchie, B. (2009). Crisis and disaster management for tourism. Bristol: Channel View Publications.

Ritchie, B., Shipway, R. and Cleeve, B. (2009). Resident perceptions of mega sporting events: a non-host city perspective of the 2012 London Olympic Games. Journal of Sport and Tourism, 14:143-167.

Roche, M. (2000). Mega-Events and Modernity: Olympics and Expos in the Growth of Global Culture, London: Routledge.

Roche, S., Spake, D. and Joseph, M. (2013). A model of sporting event tourism as economic development. Sport, Business and Management: An International Journal, 3(2):147 - 157.

Schumacher, D. (2012). Report on The Sports Travel Industry: prepared by the National Association of Sports Commissions (NASC). Available at: https://www.sportscommissions.org/Portals/sportscommissions/Documents/About/ NASC\%20Sports\%20Travel\%20Industry\%20Whitepaper.pdf $\quad$ (Accessed 1 February 2017)

Shonk, D. and Chelladurai, P. (2008). Service quality, satisfaction, and intent to return in event sport tourism. Journal of Sport Management, 22(5):587-602. 
Smith, A. (2005). Re-imaging the city: the value of sport initiatives. Annals of Tourism Research, 32(1):217-236.

Smith, A. (2006). Tourists' consumption and interpretation of sport event imagery. Journal of Sport and Tourism, 11(1):1-24.

Smith, C. and Stewart, B. (2007). The travelling fan: understanding the mechanisms of sport fan consumption in a sport tourism setting. Journal of Sport and Tourism, 12 (3-4):155-181.

Tassiopoulos, D. (2005). Event Management: A Professional and Development Approach, $2^{\text {nd }}$ ed. Cape Town: Juta.

Weed, M. (2009). Progress in sports tourism research? A meta-review and exploration of futures. Tourism Management, 30:615-628.

Weed, M. and Bull, C. (2004). Sports tourism: Participants, policy and providers. Oxford: Elsevier.

Wood, R. (2014). Sport in Egypt. Topend Sports. Available at: http://www.topendsports.com/world/countries/egypt.htm (Accessed 5 February 2017). 